\title{
Media Sosial untuk Pembelajaran Bahasa Arab pada Masa Pandemi: Kajian Kualitatif Penggunaan WhatsApp pada Sekolah Dasar di Indonesia
}

\author{
Meidiana Sahara Riqza, Muassomah \\ Universitas Islam Negeri Maulana Malik Ibrahim Malang \\ Corresponding author: meidianasahara@gmail.com
}

\begin{abstract}
Learning in the era of 5.0 society has experienced rapid mediation, especially in educational program. Teachers began to innovate using various media, especially using WhatsApp in learning Arabic Language. Arabic language has been considered as a very difficult and tedious subject for islamic elementary school children. Efforts and high creative power continue to be done to foster a fun learning of Arabic language. The purpose of this study besides want to see how the process and application of WhatsApp social media in learning Arabic language is also to increase knowledge and insight for Arabic teachers in utilizing the development of technology and information at the islamic elementary school level. This research method uses qualitative research by using descriptive analysis. Data collection techniques in this study using observations, interviews and document notes. The results of this research concluded that WhatsApp social media can facilitate for learn and long distance communication between teachers and students when they are in a pandemic, create fun learning, train students' independence, and also have more values, an environmentally friendly. This research suggests that there is more supervision of students in applying WhatsApp social media to learning Arabic language at the islamic elementary school level.
\end{abstract}

Pembelajaran di era society 5.0 telah mengalami mediatisasi yang sangat pesat khususnya di dunia pendidikan. Para pendidik mulai 
berinovasi memanfaatkan berbagai media khususnya media sosial WhatsApp dalam pembelajaran Bahasa Arab. Bahasa Arab telah dianggap sebagai pelajaran yang sangat sulit dan menjemukan bagi anak tingkat madrasah ibtidaiyah. Usaha dan daya kreasi yang tinggi terus dilakukan untuk menumbuhkan minat terhadap pelajaran Bahasa Arab. Tujuan penelitian ini selain ingin melihat bagaimana proses dan penerapan media sosial WhatsApp dalam pembelajaran Bahasa Arab juga menambah pengetahuan dan wawasan bagi guru Bahasa Arab dalam memanfaatkan perkembangan teknologi dan informasi di tingkat Sekolah Dasar. Metode penelitian ini menggunakan jenis penelitian kualitatif dengan menggunakan analisis deskriptif. Teknik pengumpulan data pada penelitian ini dengan menggunakan observasi, wawancara dan catatan dokumen. Hasil penelitian ini menemukan bahwa media sosial WhatsApp dapat mempermudah pembelajaran serta komunikasi jarak jauh antar guru dengan siswanya ketika berada pada masa pandemi, menciptakan pembelajaran yang menyenangkan, melatih kemandirian siswa, dan juga memiliki nilai lebih yaitu ramah lingkungan. Penelitian ini menyarankan adanya pengawasan yang lebih terhadap siswanya dalam mengaplikasikan media sosial WhatsApp pada pembelajaran Bahasa Arab di tingkat Sekolah Dasar.

Keywords: media sosial; WhatsApp; pembelajaran bahasa arab; madrasah ibtidaiyyah.

\section{Pendahuluan}

Pembelajaran secara daring menjadi opsi utama bagi para pendidik ketika ada instruksi langsung dari pemerintahan pusat tentang pembelajaran di rumah untuk mengantisipasi penyebaran virus corona/covid-19 ${ }^{1}$. Beragam aplikasi, website, dan media sosial menjadi perantara komunikasi

${ }^{1}$ Khasanah, D. R. A. U., Pramudibyanto, H., \& Widuroyekti, B. (2020). Pendidikan Dalam Masa Pandemi Covid-19. Jurnal Sinestesia.

Azzahra, N. F. (2020). Mengkaji Hambatan Pembelajaran Jarak Jauh di Indonesia di Masa Pandemi Covid-19. Center for Indonesians Policy Studies. 
antara guru dengan siswa ${ }^{2}$. Platform meda sosial yang paling populer digunakan adalah WhatsApp. WhatsApp adalah aplikasi perpesanan instan yang memungkinkan kita untuk mengirim file, pesan gambar, video, foto, dan obrolan online. Media sosial WhatsApp menyediakan layanan komunikasi dengan biaya yang sangat murah sehingga pengguna tidak lagi menggunakan SMS dan telpon melalui pulsa ${ }^{3}$. Selain itu dengan menggunakan WhatsApp kita juga bisa berkomunikasi tatap muka secara langgsung dengan menggunakan panggilan Video Call. ${ }^{4}$ Aplikasi WhatsApp saat dipilih karena sangat dekat dengan kita yaitu digunakan oleh semua usia remaja, orang tua, guru, dan lain-lainnya 5 . Oleh karena itu WhatsApp menjadi salah satu media sosial yang paling digemari, seiring dengan itu menawarkan berbagai fitur yang mudah diakses. Dengan berbagai macam fitur yang tersedia, peneliti memanfaatkan media sosial WhatsApp pada pembelajaran Bahasa Arab selama masa isolasi dari penyebaran virus corona/covid-19 di Madrasah Ibtidaiyah Hidayatul Mubtadiin Malang.

Bahasa Arab telah dianggap sebagai pelajaran yang sangat sulit dan menjemukan bagi anak tingkat madrasah ibtidaiyah ${ }^{6}$.

2 Zhafira, N. H., Ertika, Y., \& Chairiyaton. (2020). Persepsi Mahasiswa Terhadap Perkuliahan Daring Sebagai Sarana Pembelajaran Selama Masa Karantina Covid-19. Jurnal Bisnis Dan Kajian Strategi Manajemen.

3 Trisnani. (2017). Pemanfaatan Whatsapp Sebagai Media Komunikasi Dan WhatsApp Utilization As Media Communication and Satisfaction In Submission of Messages among People of the Community. Jurnal Komunikasi Media Dan Informatika.

4 Siti Aisyah. (2018)Artikel: "Pengaruh Pemanfaatan Whatsapp terhadap Interaksi Anak dan Orangtua Peserta Didik SMPN 10 Pontianak".

${ }^{5}$ Balasundran, K., \& Awang, M. (2020). Penggabungjalinan faktorfaktor dan hubungannya dengan pengaplikasian Whatsapp dalam kalangan guru sekolah rendah di zon Chini, Pekan. Management Research Journal, 9(2), 46-58.

6 Arifin, A. (2017). Peranan Permainan Bahasa Dalam Proses Kegiatan Belajar Mengajar Mata Pelajaran Bahasa Arab. An Nabighoh: Jurnal Pendidikan dan Pembelajaran Bahasa Arab, 19(2), 302-318. 
Butuh usaha dan daya kreasi yang tinggi untuk mengubah kesan tersebut supaya bisa menumbuhkan kecintaan terhadap pelajaran Bahasa Arab ${ }^{7}$. Oleh karena itu sebagai seorang pendidik di era yang sudah modern ini harus pandai dan cermat dalam memilih dan memilah berbagai metode, strategi, media, dan model pembelajaran yang sesuai dengan karakteristk peserta didiknya ${ }^{8}$. Kondisi dan situasi Indonesia bahkan dunia yang seperti ini bukanlah penghalang bagi para pendidik untuk selalu berkreasi dalam menciptakan pembelajaran yang inovatif dan menyenangkan ${ }^{9}$. Beberapa fitur yang sudah disediakan oleh media sosial WhatsApp bisa menjadi perantara antara para pendidik dengan siswanya.

Studi yang ada beranggapan bahwa media sosial WhatsApp memiliki dampak positif dalam hal komunikasi, koordinasi, dan diskusi tanpa harus bertemu secara langsung ${ }^{10}$. Media sosial WhatsApp juga dianggap layak dan sudah memenuhi kriteria sebagai alat bantu/instrumen pembelajaran dan meningkatkan nilai latihan mahasiswa ${ }^{11}$. Media sosial WhatsApp dapat digunakan sebagai media pembelajaran di luar kelas antar dosen dengan mahasiswa dan mahasiswa dengan mahasiswa lain, khususnya sebagai media

${ }^{7}$ Ainak, R. (2009). Implementasi Pembelajaran Bahasa Arab Model Pembelajaran Aktif, Kreatif, Efektif, dan Menyenangkan (PAKEM) di Madrasah Ibtidaiyah Sunan Pandanaran, Ngaglik, Sleman. Unpublished Paper. Yogyakarta: UIN [Universitas Islam Negeri] Sunan Kalijaga.

${ }^{8}$ Caesar, F. T. (2014). Kreativitas Guru SD Dan Kuasa Kurikulum Dalam Penerapan Kurikulum 2013. Jurnal Mahasiswa Sosiologi, 2(2).

9 Wahyono, P., \& Husamah, H. (2020). Guru profesional di masa pandemi COVID-19: Review implementasi, tantangan, dan solusi pembelajaran daring. Jurnal Pendidikan Profesi Guru, 1(1).

10 Supri Wahyudi Utomo dan Moh. Ubaidillah. (2018) Artikel: "Pemanfaatan Whatsapp pada Pembelajaran Berbasis Masalah untuk Mata Kuliah Akuntansi Internasional".

${ }^{11}$ M. Dzaky Firdaus. (2018) Skripsi: "Pengembangan Aplikasi Pesan Instan Whatsapp dalam Pembelajaran Microteaching sebagai Media Alat Bantu Belajar Mandiri Mahasiswa". 
belajar yang lebih sederhana dan efisien. Sejalan dengan itu WhatsApp memberikan pengaruh terhadap prestasi belajar mahasiswa, walaupun bukan sebagai faktor satu-satunya. ${ }^{12}$ Dari berbagai studi tersebut telah menyebutkan ada banyak dampak positif media sosial WhatsApp sehingga peneliti tertarik menggunakan WhatsApp dalam pembelajaran Bahasa Arab.

Tujuan penulisan ini ingin melihat proses pembelajaran Bahasa Arab dengan menggunakan media sosial WhatsApp dapat tercapai dengan mudah tanpa hambatan. Berhubungan dengan itu dua pertanyaan dirumuskan: (1) Bagaimana implementasi media sosial WhatsApp dalam pembelajaran Bahasa Arab di MI Hidayatul Mubtadiin; (2) Apa saja manfaat media sosial WhatsApp bagi pembelajaran Bahasa Arab.

Tulisan ini dilandaskan pada beberapa argumen bahwa penggunaan media sosial WhatsApp memberikan berbagai kemudahan, meningkatkan prestasi, dan menunjang pembelajaran Bahasa Arab di kelas. Di sisi lain, penggunaan media sosial WhatsApp ini juga masih relevan untuk siswa yang memiliki latar belakang kurang memahami IT karena pengaplikasiannya yang mudah. Media sosial WhatsApp juga bisa menjadi solusi bagi para pendidik yang belum terlalu menguasai IT supaya bisa menciptakan pembelajaran yang kreatif dan inovatif. Banyak nilai-nilai positif dalam pembelajaran bahasa arab dengan menggunakan media sosial WhatsApp, di antaranya siswa dengan lebih mudah mengakses, lebih semangat, dan melatih siswa mandiri tanpa harus dituntun secara langsung oleh guru.

\section{Media Sosial WhatsApp}

12 Hendro Kusumo Eko Prasetyo Moro. (2016) Artikel: Pengaruh Penggunaan Whatsapp Messenger terhadap Prestasi Belajar Mahasiswa". 
Media sosial kini menjadi wadah yang menarik dan menyenangkan untuk saling berkomunikasi. Banyak ragam media sosial yang tersedia secara gratis, salah satunya adalah media WhatsApp. WhatsApp adalah media sosial yang menyediakan layanan pesan instan untuk smartphone. Tidak hanya sekedar melayani pesan instan saja, WhatsApp juga dilengkapi oleh berbagai fitur menarik seperti pengiriman pesan berupa pesan teks, gambar, video, suara, maupun berkas-berkas. Selain itu WhatsApp juga dapat digunakan untuk berbagi lokasi melalui GPS. Hal menarik yang membuat WhatsApp telah diunduh oleh lebih dari satu milyar orang di seluruh dunia adalah tersedianya chat grup yang memungkinkan orang-orang yang memiliki kepentingan yang sama berkumpul dalam satu wadah komunikasi. ${ }^{13}$

Kini media sosial WhatsApp digunakan oleh semua kalangan untuk berkomunikasi secara instan dan menarik. Tidak hanya para remaja, orang tua bahkan anak-anak pun sudah tidak asing lagi menggunakan media sosial yang satu ini. Selain untuk berkomunikasi dengan keluarga, kerabat, dan sahabat, WhatsApp kini digunakan oleh para pekerja dan pelajar untuk berhubungan satu sama lain. WhatsApp memfasilitasi para pekerja dan pelajar untuk berkomunikasi lebih mudah karena beragam bentuk pesan bisa dikirim dengan sekali klik. Pesan tersebut tidak monoton hanya berbentuk teks saja tetapi bisa video, gambar, suara, dan dokumen yang berkaitan dengan pekerjaan bagi para pekerja maupun pembelajaran bagi pelajar.

Dalam dunia pendidikan WhatsApp menjadi wadah untuk berinteraksi dan menyebarkan informasi. Interaksi tersebut

${ }^{13}$ Imelda, "Pengaruh Media Sosial Whatsapp dalam Pembelajaran", diakses dari: https://www.kompasiana.com/imeldadhueego2285/5d4c42460d82303cf3275b12/pengaruh-media-sosial-whatsapp-dalampembelajaran pada tanggal 05 Mei 2020 pukul 23:00. 
bisa dilakukan antara guru dengan siswa, guru dengan guru, maupun siswa dengan siswa. Berbagai informasi yang disebarkan beragam seperti materi, tugas, dan konten menarik berkaitan dengan pembelajaran bahkan hal-hal di luar pembelajaran. Untuk mengetahui seberapa besar pengaruh media sosial WhatsApp terhadap pembelajaran telah dilakukan survei dengan lima puluh responden yang merupakan pelajar / mahasiswa / pengajar. Hampir 90\% responden menyatakan sangat setuju bahwa saat ini WhatsApp digunakan sebagai wadah untuk menyebarkan berbagai informasi yang berkaitan dengan pembelajaran. Biasanya hal tersebut dilakukan pada fitur chat grup. Sekitar $60 \%$ responden menyatakan bahwa guru cukup sering membagikan bahan ajar kepada siswa melalui grup kelas. Namun cukup disayangkan bahwa hampir 40\% responden menyatakan guru tidak terlalu sering memberikan kesempatan kepada siswa untuk berdiskusi di grup kelas. ${ }^{14}$

\section{Tren Pembelajaran Bahasa Arab di Indonesia}

Bahasa Arab merupakan salah satu bahasa dunia yang telah mengalami perkembangan sosial masyarakat dan ilmu pengetahuan. Bahasa Arab dalam kajian sejarah termasuk rumpun bahasa Semit yaitu rumpun rumpun bahasa yang dipakai bangsa-bangsa yang tinggal di sekitar sungai Tigris dan Furat, dataran Syria dan Jazirah Arabia (Timur Tengah). ${ }^{15}$ Di Indonesia bahasa Arab bisa jadi sebagai bahasa kedua bisa juga sebagai bahasa asing. Bahasa Arab bukan merupakan bahasa pergaulan sehari-hari, maka bagi lingkungan atau masyarakat pada umumnya bahasa Arab merupakan bahasa asing. Di sekolah-sekolah bahasa Arab tidak digunakan

14 Ibid.

15 Azhar Arsyad. (2003). Bahasa Arab dan Metode Pengajarannya. Surabaya: Pustaka Pelajar, 2. 
sebagai bahasa pengantar dalam pembelajaran, tetapi sebagai mata pelajaran yang terdiri dari beberapa materi. Secara formal bahasa Arab merupakan bahasa asing. Karena sebagai bahasa yang tergolong asing, sistem pembelajaran bahasa Arab adalah bahasa asing, mulai dari tujuan, materi, sampai kepada metode pembelajaran. Dengan demikian, pemerintah Indonesia telah menetapkan bahwa bahasa Arab merupakan bahasa asing, jika terdapat kalangan tertentu di Indonesia yang menganggap bahwa bahasa Arab bukan bahasa asing maka hal itu tidak resmi karena diluar patokan yang telah ditetapkan. ${ }^{16}$

Sementara itu, pembelajaran merupakan terjemahan dari bahasa Inggris "instruction" terdiri dari dua kegiatan utama, yaitu: belajar (learning) dan mengajar (teaching), kemudian disatukan dalam satu aktivitas, yaitu kegiatan belajar mengajar yang selanjutnya populer dengan istilah pembelajaran (instruction). ${ }^{17}$ Pembelajaran substansinya adalah kegiatan mengajar yang dilakukan secara maksimal oleh seorang guru agar anak didik yang ia ajari materi tertentu melakukan kegiatan belajar dengan baik. Dengan kata lain pembelajaran adalah upaya yang dilakukan oleh guru dalam menciptakan kegiatan belajar materi tertentu yang kondusif untuk mencapai suatu tujuan. Proses pembelajaran pada dasarnya merupakan rangkaian kegiatan yang dilakukan oleh guru sebagai pendidik dan siswa sebagai anak didik dalam kegiatan pengajaran dengan menggunakan sarana dan fasilitas pendidikan yang tersedia untuk mencapai tujuan yang telah ditetapkan oleh kurikulum. Pembelajaran bahasa Arab merupakan bagian dari upaya untuk mempersiapkan sejak

\footnotetext{
${ }^{16}$ Acep Hermawan. (2014) Metodologi Pembelajaran Bahasa Arab. Bandung: Remaja Rosdakarya, 56-57.

17 Tim Pengembang MKDP. (2011) Kurikulum dan Pembelajaran. Jakarta: Rajawali Pers, 180.
} 
dini agar siswa mampu dalam menguasai empat keterampilan (keterampilan menyimak, keterampilan berbicara, keterampilan membaca, dan keterampilan menulis) pengajaran bahasa ataupun memahami bahasa Arab.

Mata pelajaran bahasa Arab yaitu suatu mata pelajaran yang diarahkan untuk mendorong, membimbing, mengembangkan, dan membina kemampuan serta menumbuhkan sikap positif terhadap bahasa Arab reseptif maupun produktif. Kemampuan reseptif yaitu kemampuan untuk memahami pembicaraan orang lain dan memahami bacaan. Kemampuan produktif yaitu kemampuan menggunakan bahasa sebagai alat komunikasi baik secara lisan maupun tulis. Dalam membantu memahami sumber ajaran agama Islam yaitu Al-Qur'an, hadis, dan kitab-kitab lain yang berkenaan dengan bahasa Arab maka siswa harus mempunyai kemampuan dalam berbahasa Arab. ${ }^{18}$

Berdasarkan hal tersebut maka bahasa Arab di Sekolah Dasar dipersiapkan untuk pencapaian kompetensi dasar berbahasa, yang mencakup empat keterampilan berbahasa yang diajarkan secara integral, yaitu menyimak, berbicara, membaca, dan menulis. Meskipun begitu, pada tingkat pendidikan dasar (elementary) difokuskan pada keterampilan menyimak dan berbicara sebagai landasan berbahasa. Pada tingkat pendidikan menengah (intermediate), keempat keterampilan berbahasa diajarkan secara seimbang. Kemudian pada tingkat pendidikan lanjut (advanced) dititikberatkan pada keterampilan membaca dan menulis, sehingga siswa diharapkan mampu mengakses berbagai referensi berbahasa arab.

18 Peraturan Menteri Agama Republik Indonesia No. 2 Tahun 2008, Tentanng Standart Kompetensi Lulusan dan Standart Isi Pendidikan Agama Islam dan Bahasa Arab di Madrasah, Hal. 22. 
Pada tahap pendidikan dasar ini dapat dilakukan dengan cara menegur siswa dalam bahasa Arab, misalnya: dalam situasi ruangan yang terlalu panas atau dingin, mintalah siswa dengan bahasa Arab untuk membuka atau menutup jendela. Siswa membutuhkan keterbiasaan sesegera mungkin tentang bunyi bahasa Arab yang belum diketahui atau dikenal bagi siswa. ${ }^{19}$ Pada pembelajaran bahasa Arab di Sekolah Dasar termasuk dalam pendidikan bahasa Arab dasar yang menfokuskan terhadap aspek keterampilan menyimak dan berbicara. Difokuskan pada dua keterampilan tersebut dikarenakan agar siswa mampu mengolah kata dan memiliki kosa kata yang banyak. Ruang lingkup mata pelajaran bahasa Arab di Sekolah Dasar meliputi tema-tema tentang perkenalan, peralatan madrasah, pekerjaan, alamat, keluarga, anggota badan, di rumah, di kebun, di madrasah, di laboratorium, di perpustakaan, di kantin, jam, kegiatan seharihari, pekerjaan rumah, dan rekreasi. ${ }^{20}$

Dalam perencanaan pembelajaran bahasa Arab, tujuan pembelajaran yang akan dicapai merupakan aspek yang penting dalam mempertimbangkannya, maka dibutuhkan perencanaan yang matang. Sebab segala kegiatan pembelajaran muaranya pada tercapainya tujuan tersebut. Tujuan pembelajaran yaitu suatu pernyataan yang lebih khusus yang dinyatakan dalam perilaku atau penampilan yang diwujudkan dalam bentuk tulisan untuk menggambarkan hasil belajar yang diharapkan. ${ }^{21}$ Sasaran yang hendak dicapai pada akhir pembelajaran dan kemampuan yang harus dimiliki

${ }^{19}$ Azhar Arsyad. (2004). Bahasa Arab dan Metode Pengajarannya. Yogyakarta: Pustaka Pelajar, 69.

${ }^{20}$ Peraturan Menteri Agama Republik Indonesia No. 2 Tahun 2008, Tentanng Standart Kompetensi Lulusan dan Standart Isi Pendidikan Agama Islam dan Bahasa Arab di Madrasah, Hal. 23.

${ }^{21}$ Hamzah B. Uno. (2012) Perencanaan Pembelajaran. Jakarta: Bumi Aksara, 35. 
siswa merupakan pengertian dari tujuan pembelajaran. Mata pelajaran bahasa Arab di Sekolah Dasar atau Madrasah Ibtidaiyyah memiliki tujuan sebagai berikut :

1. Pengembangan kemampuan atau siswa dalam berkomunikasi dengan bahasa Arab, baik secara lisan maupun tulis. Bahasa Arab memiliki empat keterampilan berbahasa yaitu menyimak (istima'), berbicara (kalam), membaca (qira'ah), dan menulis (kitabah).

2. Pentingnya bahasa Arab sebagai salah satu bahasa asing yang merupakan mata pelajaran di sekolah untuk alat utama belajar dalam mengkaji sumber-sumber ajaran agama Islam, maka perlu ditumbuhkan kesadaran siswa tentang hal tersebut.

3. Pengembangan pemahaman tentang keterkaitan antara bahasa dan budaya serta memperluas kergaman budaya. Dengan demikian, siswa diharapkan memiliki wawasan lintas budaya dan melibatkan diri dalam keragaman budaya.

Dalam pembelajaran Bahasa Arab ada 3 unsur yang wajib diketahui, diantaranya :

1. Al-Aswat (bunyi)

Dalam pembelajaran bahasa, penguasaan terhadap bunyi menjadi sangat penting. Tujuan pembelajaran bunyi secara umum meliputi penguasaan seluruh sistem bunyi baik dalam bentuk mengenal dan memahami bunyi secara reseptif, maupun dalam bentuk melafalkan dan menggunakan bunyi bahasa secara aktif produktif. Selain dalam bentuk konsonan dan vokal, sistem bunyi meliputi tinggi rendahnya suara (alThul), tekanan kata dan kalimat (al-Nabr), intonasi (alTanghim), dan sebagainya. ${ }^{22}$

2. Al-Mufrodat (kosakata)

${ }^{22}$ Abdul Wahab Rosyidi. (2009). Media Pembelajaran Bahasa Arab. Malang: UIN Malang Press, 53. 
Penyampaian pesan bahasa menuntut penggunanya untuk bisa memilih kosakata yang tepat dan sesuai agar dapat mengungkapkan makna yang dikehendaki. Pemahaman yang tepat terhadap pesan yang disampaikan melalui bahasa banyak ditentukan oleh pemahaman dan penggunaan yang tepat terhadap kosakata yang digunakan dalam percakapan tersebut. $^{23}$

3. Al-Qawaid (tata bahasa)

Al-Qawaid merupakan salah satu komponen bahasa yang penting dan tidak terpisahkan berkaitan dengan penataan kata dalam merangkai kata-kata. Selain itu, tata bahasa juga berkaitan dengan perubahan bentuk kata dalam bahasa Arab. Tujuan pembelajaran tata bahasa secara garis besar meliputi pemahaman dan penggunaan pembentukan kata, frasa dan kalimat. $^{24}$

\section{Metode}

Jenis penelitian ini penelitian kualitatif dengan menggunakan analisis deskriptif. Penelitian deskriptif dirancang untuk memperoleh data tentang keadaan, status, atau gejala pada saat penelitian dilakukan. Penggunaan metode deskriptif yang dimaksud dalam penelitian ini adalah memperoleh gambaran secara menyeluruh mengenai permasalahan yang diteliti berkaitan dengan penerapan media sosial WhatsApp dalam pembelajaran Bahasa Arab. Menurut Sugiyono penelitian kualitatif deskriptif adalah metode penelitian yang dilandaskan pada filsafat postpositivisme yang biasanya digunakan untuk meneliti pada kondisi objektif alamiah dimana peneliti berperan sebagai instrumen kunci. ${ }^{25}$ Pada penelitian ini peneliti menjadi alat

${ }^{23}$ Abdul Wahab Rosyidi, Media Pembelajaran..., 56.

24 Ibid, 60.

${ }^{25}$ Sugiyono. (2013) Metode Penelitian Kuantitatif Kualitatif dan R \& D. Bandung: Alfabeta, 15. 
peneliti utama yang mana melakukan penelitian langsung dan aktif mengumpulkan berbagai materi atau bahan yang berkaitan dengan penelitian. Guna menemukan hasil penelitian maka peneliti menempuh beberapa langkah yaitu pengumpulan data, pengolahan data, penyusunan laporan serta penarikan kesimpulan.

Teknik pengumpulan data pada penelitian ini dengan observasi, wawancara dan catatan dokumen. Observasi dilakukan untuk menggali data terkait, dengan cara mengamati proses kegiatan pembelajaran Bahasa Arab secara langsung di grup WhatsApp. Wawancara, kegiatan wawancara ini dilakukan dengan guru pengajar Bahasa Arab dan juga siswa Madrasah Ibtidaiyah Hidayatul Mubtadiin kelas 4B. Wawancara kepada guru dibutuhkan untuk memperoleh data yang terpapar jelas tentang implementasi (perencanaan, pelaksanaan, dan evaluasi) media sosial whatsap pada pembelajaran Bahasa Arab begitu juga manfaat yang diperoleh oleh guru tersebut. Wawancara kepada siswa diperoleh berbagai informasi tentang pendapat dan juga manfaat dari pembelajaran Bahasa Arab dengan menggunakan WhatsApp. Jenis wawancara yang digunakan yaitu wawancara terkontrol dengan menggunakan pedoman wawancara, namun dilaksanakan secara bebas sehingga data yang diperoleh lebih obyektif. Catatan dokumen, instrumen ini digunakan untuk mengetahui data tertulis yang ada di sekolahan tersebut yang berupa silabus, RPP, dan buku-buku pembelajaran Bahasa Arab.

Teknik analisa data yang digunakan dalam menganalisis data yaitu bersifat kualitatif yang digambarkan dengan katakata atau kalimat yang dipisahkan menurut kategori untuk memperoleh kesimpulan. Dalam konteks ini peneliti mendeskripsikan secara kualitatif gambaran umum tentang 
pembelajaran Bahasa Arab dengan menggunakan media sosial WhatsApp.

\section{Hasil dan Pembahasan}

\section{Implementasi Media Sosial WhatsApp dalam Pembelajaran Bahasa Arab di Madrasah Ibtidaiyah Hidayatul Mubtadiin}

Pada masa pandemi ini berbagai metode telah dicoba atau dipelajari oleh para pendidik supaya sebisa mungkin dalam menyampaikan materi pelajaran menjadi kondusif dan efektif. Pengajar Bahasa Arab di kelas 4 B Madrasah Ibtidaiyah Hidayatul Mubtadiin telah memutuskan mengajar secara daring dengan menggunakan media sosial WhatsApp kepada siswa-siswanya setelah mencoba menggunakan googleclassroom bahkan juga zoom dirasa kurang efektif bagi siswa-siswanya. Pada aplikasi WhatsApp pengajar bisa dengan bebas berinteraksi dengan siswa tanpa membutuhkan banyak kuota internet. Begitu juga siswa tidak merasa kesulitan ketika menggunakan aplikasi tersebut secara mandiri. Semisal ketika guru menyampaikan materi maharah qiroah di grup WhatsApp, siswa tinggal membaca kemudian setor melalui fitur voicenote yang ada di WhatsApp. Apabila ada materi hiwar maka siswa akan memperagakan hiwar dengan orangtuanya atau bisa saudaranya kemudian divideo dan dikirim di grup WhatsApp kelas. Dan ketika guru mengadakan ulangan harian bisa dengan mudah mengirim file atau videovideo yang bisa dipelajari oleh siswa. Komunikasi dengan siswa meskipun jarak jauh menjadi mudah menggunakan aplikasi WhatsApp.

Berikut ini adalah rencana pembelajaran Bahasa Arab kelas 4B di MI Hidayatul Mubtadiin selama masa pandemi :

1. Rencana Pembelajaran Bahasa Arab berbasis WhatsApp

a. Membuat grup WA, setiap peserta didik dimasukkan grup 
b. Menyepakati aturan untuk tidak mengirim pesan yang tidak ada sangkut pautnya dengan pembelajaran, selalu aktif mengikuti pembelajaran meskipun tidak bertatap muka langsung, dan orangtua ikut berpartisipasi dalam memantau pembelajaran anaknya.

c. Guru memulai pembelajaran diawali dengan mengucap salam dan menanyakan kabar dengan menggunakan bahasa Arab dan direspon balik oleh peserta didik melalui voice note.

d. Guru memberikan list daftar hadir dan diisi oleh peserta didik.

e. Guru memberikan beberapa mufrodat terkait dengan bab yang dipelajari, peserta didik mencatat, menghafalkannya, dan mengirim dalam bentuk video.

f. Guru memberikan bacaan bahasa Arab dengan mencontohkan cara membaca, peserta didik mencoba membaca dan menerjemahkan kemudian dikirim ke guru melalui voice note dan hasil jawaban difoto.

g. Guru memberi tugas memperagakan hiwar yang ada di bacaan kemudian dikirim dalam bentuk video di grup kelas.

h. Guru membahas dan menerjemahkan bacaan di grup, peserta didik menyimak dan membetulkan jawaban yang salah.

i. Guru memberikan materi tarkib seperti huruf jer beserta dengan contoh bacaan/kalimat yang mudah dipahami. 
Meidiana Sahara Riqza, Muassomah

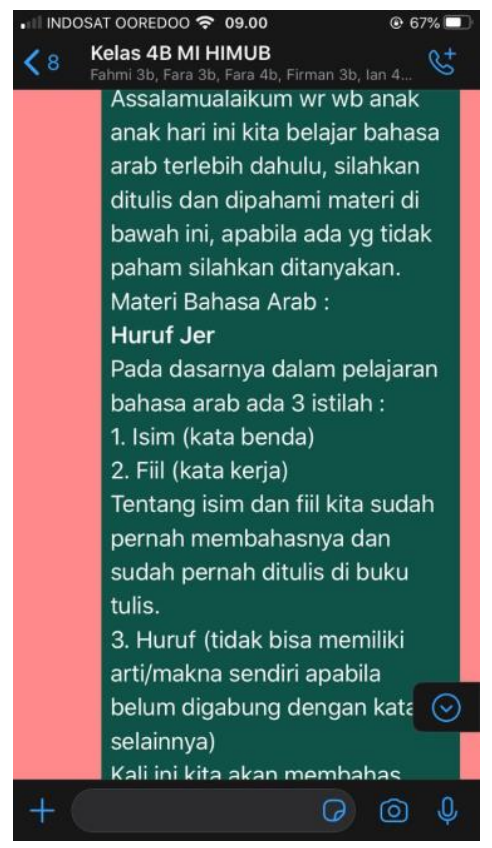

j. Peserta didik merespon dengan bertanya apabila dirasa kurang memahami setelah itu mencatat materi tersebut.

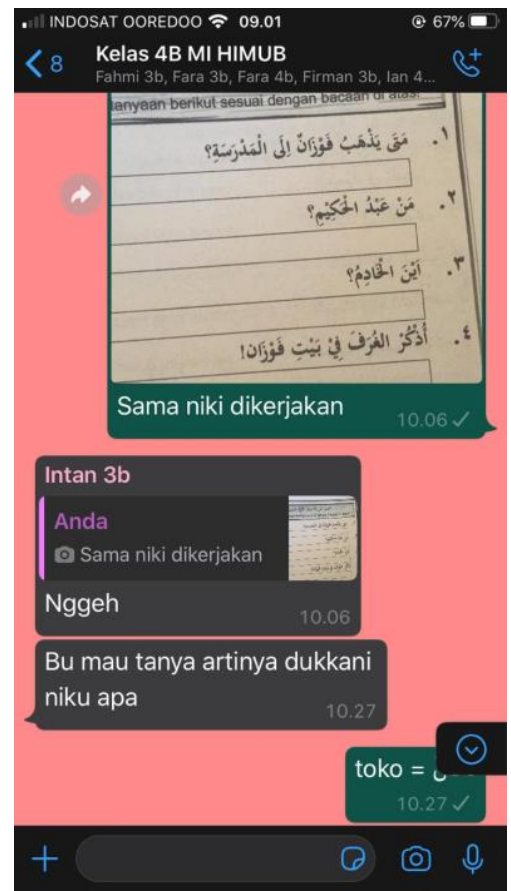


Media Sosial untuk Pembelajaran Bahasa Arab pada Masa Pandemi

k. Guru memberikan beberapa soal latihan terkait dengan apa yang sudah dipelajari peserta didik.

l. Peserta didik menjawab soal kemudian jawaban difoto dan dikirimkan ke wa pribadi guru.

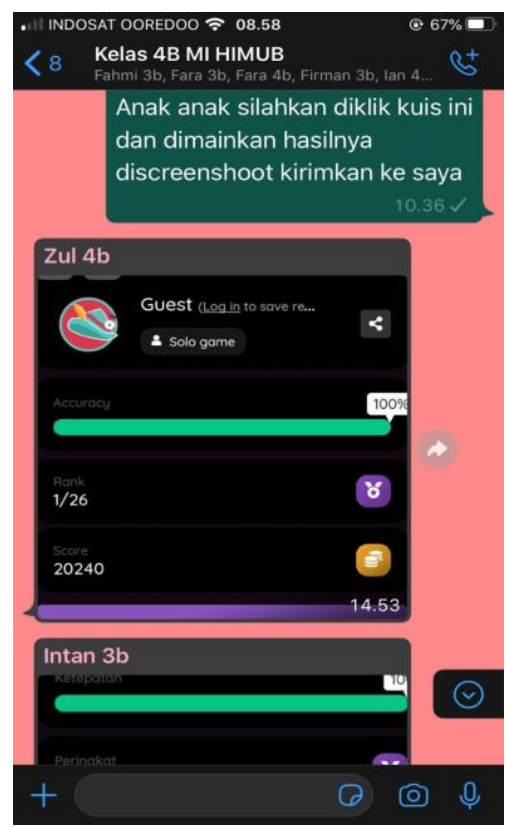

m. Guru memberikan feedback terhadap hasil latihan siswa dan menjelaskan ulang apabila dirasa peserta didik kurang memahami. 


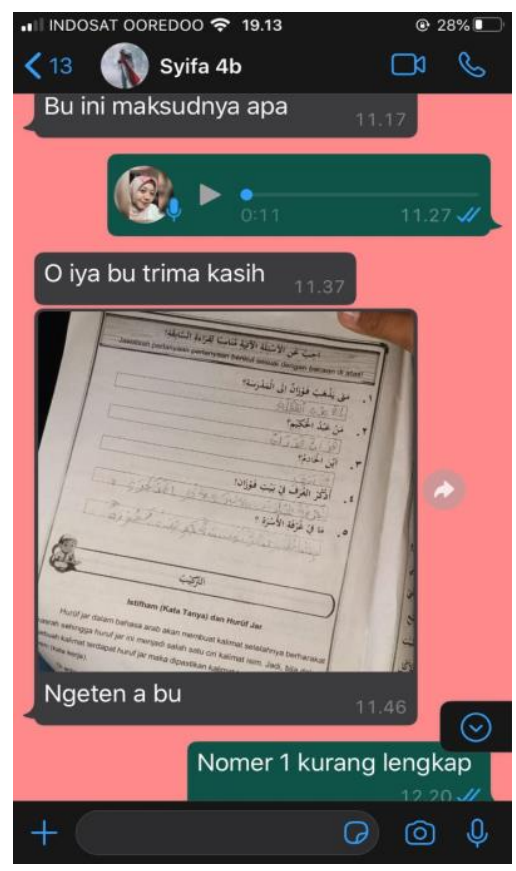

\section{Manfaat Media Sosial WhatsApp bagi Pembelajaran Bahasa Arab}

WhatsApp sebagai media sosial sangat memungkinkaan dimanfaatkan oleh guru atau pendidik sebagai media pembelajaran. Penggunaan media pembelajaran yang inovatif dan bervariasi sangat diperlukan dalam pembelajaran Bahasa Arab. Kemajuan teknologi yang semakin pesat di bidang komunikasi telah melahirkan banyak inovasi dan gagasan baru, ide yang bertujuan untuk memudahkan proses komunikasi sehingga menjadi lebih efektif. Dalam kemajuan teknologi informasi juga dapat berhubungan dengan orang lain tanpa ada batasan jarak dan waktu.

Penggunaan media sosisal WhatsApp memiliki beberapa manfaat bagi para guru, para pendidik, begitu juga dengan siswa dalam ruang lingkup pembelajaran terutama Bahasa Arab. Bagi seorang guru media sosial WhatsApp memberikan kemudahan ketika tidak bisa bertemu secara langsung dengan 
peserta didik dengan memanfaatkan diskusi grup untuk melatih kalam atau menambah jumlah mufrodat siswa, bisa menghemat efisiensi waktu dan tenaga dalam menyampaikan materi atau informasi, dan bisa dijadikan sebagai sarana evaluasi pembelajaran. Media sosial WhatsApp ini juga bisa memacu guru untuk lebih berkreasi dalam memberikan materi, latihan, baik melalui video, audio, atau secara tertulis. Bagi seorang siswa, media sosial WhatsApp juga memiliki banyak manfaat yang banyak diantaranya bisa merubah kegiatan pembelajaran bahasa Arab menjadi menyenangkan, lebih efisien, dan tidak membosankan. Dengan menggunakan WhatsApp siswa bebas berdiskusi dan bertanya kepada guru bahkan teman sekelasnya tanpa ada batasan jam pembelajaran. Siswa akan terlatih belajar secara mandiri dengan memanfaatkan berbagai fitur WhatsApp. Penggunaan WhatsApp juga memiliki nilai lebih, yaitu ramah lingkungan karena bisa menghemat penggunaan kertas untuk mengerjakan tugas yang diberikan, begitu juga sebaliknya dengan guru.

\section{Kesimpulan}

Berdasarkan uraian data diatas peneliti menemukan beberapa kesimpulan bahwa dalam penerapan media WhatsApp dalam pembelajaran bahasa Arab di MI Hidayatul Mubtadiin, peran orang tua sangat dibutuhkan dalam memantau bahkan harus terlibat dalam membantu anaknya ketika merekam tugas dan lain-lain. Karna pada anak usia sekolah dasar tidak semuanya mahir dalam mengaplikasikan gadget. Peran guru juga lebih intens disini karena bisa lebih dekat dengan peserta didik melalui chat pribadi yang mana biasanya ketika di kelas peserta didik malu untuk bertanya dan menyampaikan keluh kesah atau kesulitan dalam hal pembelajaran dan bisa bebas berkomunikasi dengan guru 
tanpa terikat jam pertemuan dalam kelas. WhatsApp juga dianggap sebagai media sosial yang tepat untuk wadah berinteraksi seputar pembelajaran di luar kelas. Akan tetapi juga ada beberapa kendala dalam penerapan media sosial WhatsApp dalam pembelajaran bahasa Arab yaitu keaktifan peserta didik yang tidak menyeluruh di grup kelas karena terkadang ada beberapa peserta didik yang kehabisan paket data internet atau kesulitan sinyal. Oleh karena itu sebagai orangtua dan guru agar lebih protektif terhadap anak/siswanya ketika melaksanakan pembelajaran berbasis daring dengan menggunakan media sosial WhatsApp.

Penelitian memiliki keterbatasan, penerapan media sosial WhatsApp pada pembelajaran Bahasa Arab hanya bisa dilaksanakan di luar kelas karena ketika sekolah siswa tidak diperbolehkan membawa gadget. Penggunaan media sosial WhatsApp ini juga hanya sebagai ganti pembelajaran tatap muka secara langsung. Dan menyarankan dalam pembelajaran jarak jauh guru harus melakukan banyak inovasi, media, dan strategi pembelajaran yang dapat mendukung pembelajaran Bahasa Arab supaya tidak monoton. Siswa pun juga harus bijak dalam menggunakan media sosial dengan adanya dampingan dari orangtua masing-masing.

\section{Daftar Pustaka}

Ainak, R. (2009). Implementasi Pembelajaran Bahasa Arab Model Pembelajaran Aktif, Kreatif, Efektif, dan Menyenangkan (PAKEM) di Madrasah Ibtidaiyah Sunan Pandanaran, Ngaglik,

Aisyah, Siti. (2018). Artikel: Pengaruh Pemanfaatan WhatsApp terhadap Interaksi Anak dan Orangtua Peserta Didik SMPN 10 Pontianak. 
Arifin, A. (2017). Peranan Permainan Bahasa Dalam Proses Kegiatan Belajar Mengajar Mata Pelajaran Bahasa Arab. An Nabighoh: Jurnal Pendidikan dan Pembelajaran Bahasa Arab, 19(2), 302-318.

Arsyad, Azhar. (2003). Bahasa Arab dan Metode Pengajarannya. Surabaya: Pustaka Pelajar.

Arsyad, Azhar. (2004). Bahasa Arab dan Metode Pengajarannya. Yogyakarta: Pustaka Pelajar.

Azzahra, N. F. (2020). Mengkaji Hambatan Pembelajaran Jarak Jauh di Indonesia di Masa Pandemi Covid-19. Center for Indonesians Policy Studies.

Balasundran, K., \& Awang, M. (2020). Penggabungjalinan faktor-faktor dan hubungannya dengan pengaplikasian WhatsApp dalam kalangan guru sekolah rendah di zon Chini, Pekan. Management Research Journal, 9(2), 46-58.

Caesar, F. T. (2014). Kreativitas Guru SD Dan Kuasa Kurikulum Dalam Penerapan Kurikulum 2013. Jurnal Mahasiswa Sosiologi, 2(2).

Firdaus, M. Dzaky. (2018). Skripsi: Pengembangan Aplikasi Pesan Instan WhatsApp dalam Pembelajaran Microteaching sebagai Media Alat Bantu Belajar Mandiri Mahasiswa.

Hermawan, Acep. (2014). Metodologi Pembelajaran Bahasa Arab. Bandung: Remaja Rosdakarya.

Imelda. 2019. Pengaruh Media Sosial WhatsApp dalam Pembelajaran. Dalam : https://www.kompasiana.com/imeldadhueego2285/5d4c42460d82303cf3275b12/pengaruh -media-sosial- WhatsApp -dalam-pembelajaran pada tanggal 05 Mei 2020 pukul 23:00. 
Khasanah, D. R. A. U., Pramudibyanto, H., \& Widuroyekti, B. (2020). Pendidikan Dalam Masa Pandemi Covid-19. Jurnal Sinestesia.

Moro, Hendro Kusumo Eko Prasetyo. (2016). Artikel: Pengaruh Penggunaan WhatsApp Messenger terhadap Prestasi Belajar Mahasiswa.

Peraturan Menteri Agama Republik Indonesia No. 2 Tahun 2008, Tentang Standart Kompetensi Lulusan dan Standart Isi Pendidikan Agama Islam dan Bahasa Arab di Madrasah.

Sleman. Unpublished Paper. Yogyakarta: UIN [Universitas Islam Negeri] Sunan Kalijaga.

Sugiyono. (2013). Metode Penelitian Kuantitatif Kualitatif dan $R \& D$. Bandung: Alfabeta.

Tim Pengembang MKDP. (2011). Kurikulum dan Pembelajaran. Jakarta: Rajawali Pers.

Trisnani. (2017). PEMANFAATAN WhatsApp SEBAGAI MEDIA KOMUNIKASI DAN WhatsApp Utilization As Media Communication and Satisfaction In Submission of Messages among People of the Community. Jurnal Komunikasi Media Dan Informatika.

Uno, Hamzah B. (2012). Perencanaan Pembelajaran. Jakarta: Bumi Aksara.

Utomo, Supri Wahyudi dan Moh. Ubaidillah. (2018). Artikel: Pemanfaatan WhatsApp pada Pembelajaran Berbasis Masalah untuk Mata Kuliah Akuntansi Internasional.

Wahab Rosyidi, Abdul. (2009). Media Pembelajaran Bahasa Arab. Malang: UIN Malang Press. 
Media Sosial untuk Pembelajaran Bahasa Arab pada Masa Pandemi

Wahyono, P., \& Husamah, H. (2020). Guru profesional di masa pandemi COVID-19: Review implementasi, tantangan, dan solusi pembelajaran daring. Jurnal Pendidikan Profesi Guru, 1(1).

Zhafira, N. H., Ertika, Y., \& Chairiyaton. (2020). Persepsi Mahasiswa Terhadap Perkuliahan Daring Sebagai Sarana Pembelajaran Selama Masa Karantina Covid-19. Jurnal Bisnis Dan Kajian Strategi Manajemen. 
